\title{
異なる表面粗さを有する被測定物の \\ 高精度三次元測定機によるスキャニング測定 \\ High precision CMM scanning measurement for the work \\ with a different surface roughness
}

\section{○学 藤岡 拓寛（九州大） 正 黒河 周平（九州大） 松川 洋二（九州大）}

Takuhiro FUJIOKA, Kyushu University, Motooka 744, nishi-ku, Fukuoka Syuhei KUROKAWA, Kyushu University

Yoji MATSUKAWA, Kyushu University

Key Words: Coordinate Measuring Machine(CMM), Scanning measurement

\section{1. 緒言}

三次元測定機（CMM : Coordinate Measuring Machine）は 互いに直交する $\mathrm{X}, \mathrm{Y}$ ，および $\mathrm{Z}$ 軸を利用して多種多様な 製品の自動・高速三次元座標測定を行うことができる機器 であり，その用途の広さから製造業での導入が拡大してい る。それに伴い，幅広い測定対象に対する高精度測定の要 求が高くなってきており, さらなる性能の向上が求められ ている。しかし三次元測定には，測定機自身や測定環境な どに起因する様々な不確かさ要因が存在し, 測定結果に大 きな影響を与えることが考えられる. 不確かさ要因の中で も, 被測定物の形状誤差や表面粗さが測定対象の広範囲化 により問題となる。特に, 接触式プローブでのスキャニン グ測定では，スキャニングスピードなどのスキャニングパ ラメータと被測定物の表面粗さが測定結果に大きな影響を 与えている。この問題を解決するには, 表面粗さとスキャ ニングパラメータの関係性の解明が必要不可欠となる.

そこで, 本研究では高精度三次元測定機を使用し, 均一 な表面粗さを有するいくつかの被測定物のスキャニング測 定を行うことで, 被測定物の表面粗さとスキャニングパラ メータの関係を確認し, 測定結果への影響を調査した.

\section{2. 実験装置}

使用した三次元測定機の外観写真と機械座標系を図 1 に 示す。本研究では超高精度測定が可能な三次元測定機 （Mitutoyo 社製 LEGEX776）を使用し実験を行った。使用 した接触式プローブのスタイラス直径は $4 \mathrm{~mm}$ とした。

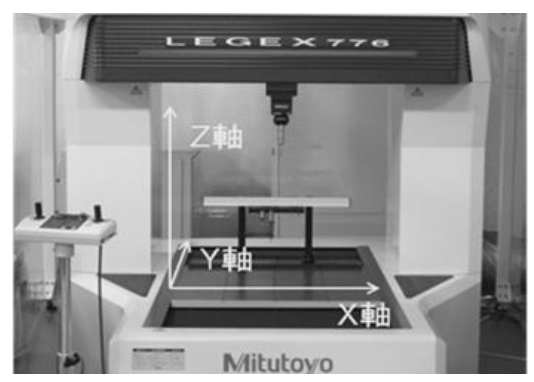

Fig. 1 Coordinate Measuring Machine and machine coordinate system

\section{3. 被測定物}

本研究では直径 $50 \mathrm{~mm}$, 長さ $250 \mathrm{~mm}$ の円筒形状の工作 物が均一な表面粗さを有する様に旋削加工を施した．表 1
に工作物の加工条件を示す. 今回はコーナ半径 $0.8 \mathrm{~mm}$ の 工具を使用し，送り量を変更することで， A， B，Cの 3 種 類の異なる表面粗さを有する工作物を作成した.

Table 1 Cutting condition

\begin{tabular}{|c|c|c|c|}
\hline Workpiece & A & B & C \\
\hline Corner radius $[\mathrm{mm}]$ & 0.8 & 0.8 & 0.8 \\
\hline Feed $[\mathrm{mm} / \mathrm{rev}]$ & 0.36 & 0.51 & 1.5 \\
\hline Theoretical roughness $[\mu \mathrm{m}]$ & 20.25 & 40.6 & 351.56 \\
\hline
\end{tabular}

\section{4. 表面粗さとスタイラスチップの関係}

図 2 にスタイラスチップと表面粗さの関係を図示した. 工作物の表面をスキャニングした際にスタイラスチップ中 心の包絡線は図 2 に示寸ような形状になる。 その中心座標 が描く包絡線の最大幅は式(1) から求めることが出来る.式 (1)より, スタイラスチップ中心の挙動は, スタイラスチッ プ直径と旋削時の送り量に依存することが分かる。したが って，前章で示した被測定物のスキャニング測定を行うこ とで，異なる表面粗さがスキャニング測定結果にどの様な 影響を与えるか調査することが出来る.

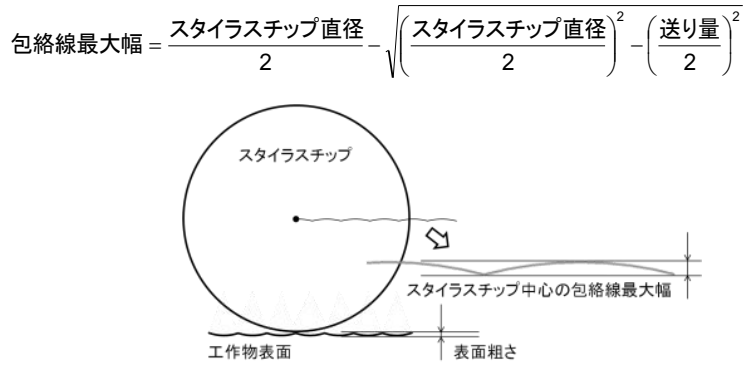

Fig. 2 Relationship between surface roughness and envelop curve by stylus tip scanning

\section{5. スキャニング測定}

前章で示した工作物の母線の中心付近 $30 \mathrm{~mm}$ の範囲を 工作物の軸方向にスキャニング測定した。サンプリング間 隔は $0.01 \mathrm{~mm}$ としている.

5-1. 繰り返し性の確認

スキャニング測定の繰り返し性について検証する。図 3 にそれぞれの工作物に対してスキャニングスピードを 1.0 $\mathrm{mm} / \mathrm{s}$, 押し込み量を $0.3 \mathrm{~mm}$ として, 測定を 10 回繰り返し たデータを示す．横軸が X 軸方向，縦軸が Z 軸方向の変位 
である．また表 2 にばらつきを示す，本研究では，ばらつ きとして，10 個の測定データの内，1つのデータを基準と して, 基準からのそれぞれデータの差分の平均值を取って いる. 図 3 に着目すると, 包絡線の最大幅に対する相対的 なばらつきが見られた。また，表 2 に着目すると，それぞ れの工作物において差分によるばらつきの值はすべて近い オーダを示しており, 被測定物の表面粗さの大きさに起因 する，ばらつきの大きさの違いは見られなかった。

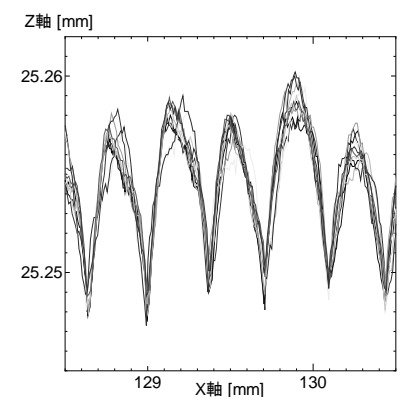

(a) Workpiece $\mathrm{A}$

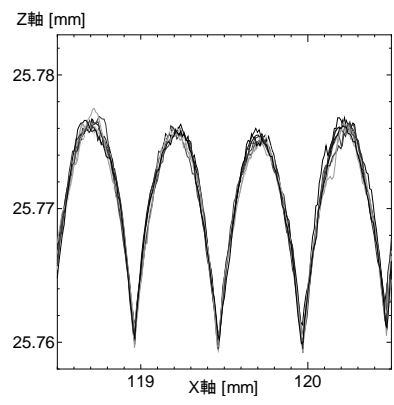

(b) Workpiece B

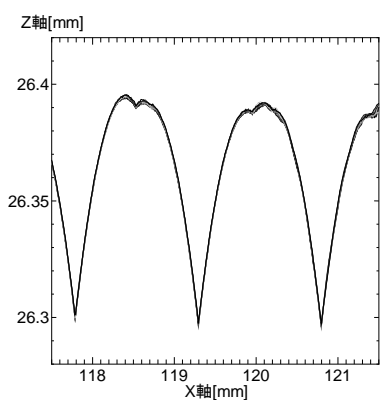

(c) Workpiece C
Fig. 3 Repeatability of scanning measurement

Table 2 Dispersion of scanning measurement

\begin{tabular}{|c|c|c|c|}
\hline Workpiece & A & B & C \\
\hline Dispersion $[\mu \mathrm{m}]$ & 1.78 & 0.73 & 0.76 \\
\hline
\end{tabular}

\section{5-2. スキャニングスピードの変更}

スキャニングパラメータを変更し，測定結果に表れる影 響を調查した。図 4 にそれぞれの工作物に対してスキャニ ングスピードを $1.0 \mathrm{~mm} / \mathrm{s}, \quad 3.0 \mathrm{~mm} / \mathrm{s}, \quad 7.0 \mathrm{~mm} / \mathrm{s}, \quad 10.0 \mathrm{~mm} / \mathrm{s}$ と変化させて測定したデータを示す，横軸が X 軸方向，縦 軸が Z 軸方向の変位である。この時，押し込み量は $0.3 \mathrm{~mm}$ としている。(a)に着目すると, 繰り返し性の検証時と同様 なばらつきがみられた，次に，(b)に着目すると，スキャニ ングスピードを増加させることで，表面粗さの山の部分を 測定する際に, $\mathrm{Z}$ 軸方向への変位が増加していることが分 かった．最後に，(c)に着目すると，(a)と同様ばらつきに大 きな変化が見られなかった。

以上の結果から，工作物 B に関しては，スキャニングス ピードの変化が測定結果に影響を与えていることが確認で きる. その原因について考察するために，Y 軸方向の変位 について着目した. 図 5 に工作物 B を測定する際のスキャ ニングスピードの変更に対する $\mathrm{Z}$ 軸方向および，Y 軸方向 の変位を示す．図 5 に着目すると，スキャニングスピード が遅い時には Y 軸方向に周期的な変位が発生し, 速くなる と変位が減少することが分かる。これは，スキャニングス ピードが遅い時は, 表面粗さの影響でスタイラスチップが Y 軸方向に変位していることが考えられる，一方，スキャ
ニングスピードが増加することで, 表面粗さの谷の部分を 十分に捉えることが出来ておらず，さらに山の部分でスタ イラスチップが跳ねていることが考察される.

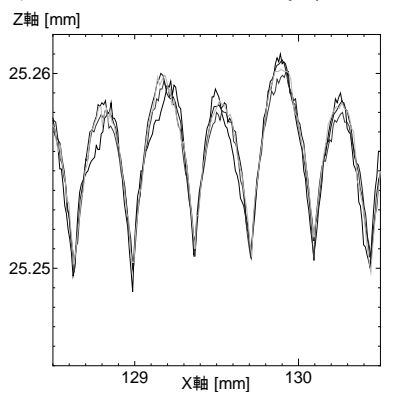

(a) Workpiece $\mathrm{A}$

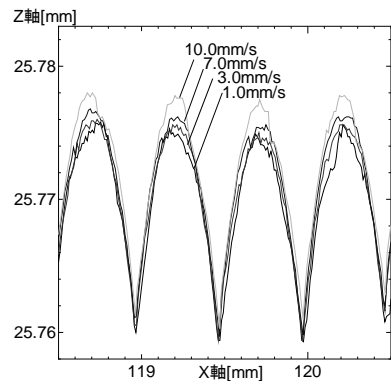

(b) Workpiece B

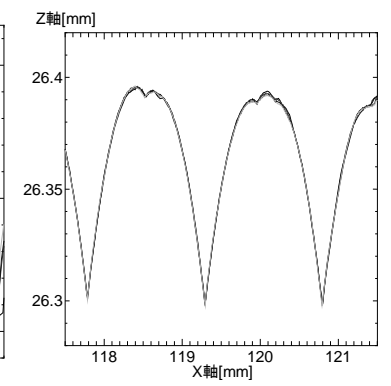

(c) Workpiece C
Fig. 4 Change of scanning speed

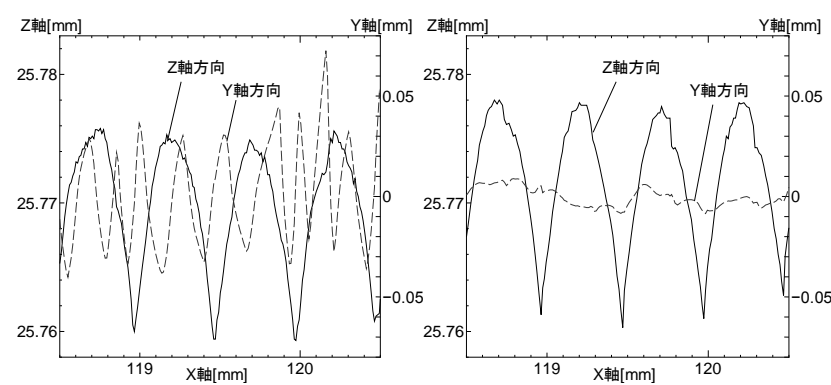

(a) Scanning speed $1.0 \mathrm{~mm} / \mathrm{s}$ (b) Scanning speed $10.0 \mathrm{~mm} / \mathrm{s}$ Fig. 5 Displacement of y-axis and z-axis for Workpiece B

\section{6. 結言}

今回は，測定物表面粗さとスキャニングパラメータの関 係性を調べ，測定結果への影響を調查した。その結果，得 られた知見を以下に示す.

1) 表面粗さの大きさに起因する, スキャニング測定の繰 り返し性の違いは見られなかった。

2) 工作物 B に関しては, キャニングスピードを増加させ ることで, 表面粗さの山の部分で $\mathrm{Z}$ 軸方向への変位が 増加した。

3）スキャニングスピードが遅い場合には Y 軸方向への 周期的な変位が見られ，速くなると減少した。

以上より，表面粗さのスキャニング測定への影響を検証 し，スキャニング測定の高精度化への可能性が示された.

\section{文 献}

1）大澤尊光，高辻利之，佐藤理，ものづくり産業を支える高精 度三次元形状測定, Synthesiology,vol.2 No.2,(Jun.2009), pp.101-112 